\title{
Inward Foreign Direct Investment and Economic Development: A Global Perspective
}

\author{
K. V. Bhanu Murthy* and Manoj Kumar Sinha**
}

\begin{abstract}
The economic basis of globalisation lies in multilateralism where the intended impact is allocative efficiency. So, it can be said about foreign direct investment (FDI) that multilateralism implies importing capital from a variety of sources as may be most efficient rather than restricting them to a bilateral basis. This forms the motivation of this paper. This paper has used principal component analysis (PCA) and panel regression approaches. The study builds up a methodology for measuring and testing the determinants of the patterns of global inward FDI. These determinants are a large set of developmental variables. The study evolves a set of six composite indices by using of PCA, namely human resource, infrastructure, labour, market, trade openness and resource. The results establish certain basic principles of FDI theory in terms of efficiency-seeking FDI, resource-seeking FDI and market-seeking FDI.
\end{abstract}

Keywords: FDI, Capital, Economic Development, Panel Regression, Composite Index.

\subsection{Introduction}

Globalisation is generally defined as opening up of markets, leading to transfer of capital, technology and people. However, another important dimension of globalisation is multilateralism. It would be obvious that the former cannot be effective without later. One of the major objectives is of international economic reforms was to encourage multilateralism. The economic basis of multilateralism lies in allocative efficiency. This implies that economies are able to import from most efficient sources and are able to export to the best destinations. In an analogous manner, it can be said about Outward Foreign Direct Investment (FDI) that multilateralism implies importing capital from a variety of sources as may be most efficient rather than restricting to a bilateral basis. Similarly, the obverse of this phenomenon would be to export capital where it can be most efficiently utilised, by combining capital with other resources optimally.

* Professor, Department of Commerce, Delhi School of Economics, University of Delhi ** Assistant Professor, Department of Commerce, PGDAV College, University of Delhi 
54 | FOCUS: Journal of International Business, Vol. 2, Issue 1

These capital transfers should work as a two way relationship. Foreign Direct Investment (FDI) could promote economic development and economic development could promote FDI. Further, there have been inward capital movements and outward capital movements. The paper concentrates on global inward capital flows and studies the effect of economic development on inward FDI. Most of the extant literature is on the reverse causality.

The layout of the paper is as follows. In Section 2, we shall be discussing the rationale of the study and the hypotheses. Section 3 gives the literature review. Section 4 lays out the methodology and section 5 gives the results and analysis. The last section summarises the conclusions.

\subsection{Rationale of the study}

With globalisation, development has become a global issue. The expectation out of globalisation is that it will promote international investment flows, so that there is global development, universally. The problem caused by FDI theory is about explaining international capital flows in a generalised framework. It ought to be generalised in two senses: (i) It should be inclusive (developed and developing countries); and (ii) It should be based on countries rather than firms.

Thus the rationale for studying of international FDI patterns arises from two stand points:

a) With globalisation (WTO) and liberalisation international long-term capital flows in the form of FDI are promoted. Capital is the complementary input to labour, natural resources, infrastructure etc. This leads to international relocation of production. If such flows follow rational allocation, it will lead to global optimum allocation of resources and global economic welfare (Dunning, 1977, 1998).

b) If the above happens there must be a visible relationship between socio-economic variables (economic development) such as labour, human resource, infrastructure, openness, market, and resources; and the patterns of FDI inflows globally.

The paper considers a set of hypotheses that could validate the relationship between inward FDI and economic development.

\subsection{Hypotheses}

The primary objective of the study is to assess the impact of developmental variables on global FDI inflows and inward stock. Accordingly, we formulate the following hypotheses.

$\mathrm{H}_{1}$ : Human resources do not affect OFDI. 
$\mathrm{H}_{2}$ : Infrastructure does not affect OFDI.

$\mathrm{H}_{3}$ : Labour does not affect OFDI.

$\mathrm{H}_{4}$ : Market does not affect OFDI.

$\mathrm{H}_{5}$ : Trade openness does not affect OFDI.

$\mathrm{H}_{6}$ : Resources do not affect OFDI.

These hypotheses are tested with the help of an elaborate methodology laid out in section 4.

\subsection{Literature Review}

We review some of the important studies in the area of FDI in this section. Banga (2003) highlights the importance of government policies in attracting FDI inflows into developing countries. They show that apart from the economic fundamentals of the economy, which may attract FDI inflows, FDI policies of the host governments and investment agreements also play an important role within the national FDI policies adopted by the government, it is the removal of restrictions on the operations of foreign firms in the host country that matter the most, especially to FDI coming from developed countries. Economic fundamentals differ in terms of their significance in attracting FDI from developed countries and developing countries. FDI from developed countries are attracted to large market size, higher education levels, higher productivity of labour, better transport and communication and lower domestic lending rates, while cost factors play a more significant role in attracting FDI from developing countries.

Palit and Nawani (2007) identify the reasons behind some developing economies from Asia being able to consistently attract more FDI than others in the region. The paper examines whether the success of these economies in getting more FDI can be explained by their technological capabilities and modern IT-based communications infrastructure. The findings of the paper indicate that with production processes becoming more complex and technology-intensive, domestic technological capabilities, particularly innovative capacities, along with the ability to apply such innovations efficiently through advanced IT-based techniques, have become more important locational advantages than cheap labour. The level and quality of technological development achieved by different developing Asian economies does explain why some of them have remained attractive destinations for FDI, while others have fallen behind. The more mature Asian 'Tigers' - Hong Kong, Korea, Singapore - and China continue to be the top FDI destinations in developing Asia, while the 'new' Tigers Indonesia, Malaysia, Thailand and the Philippines - are not so any longer.

Mottaleb (2007) finds out the influential factors that determine the FDI inflows. To find out the influential factors, the socio-economic condition of the sample top and low FDI 
recipient countries is compared. The findings show that top FDI recipient countries in 2005 have large domestic market with high GDP growth rate. They are also well equipped with modern infrastructure, such as telephone and internet. Moreover, business environment in the top FDI recipient countries in 2005 is friendlier compared to other countries indicated by high score of corruption perception index and low business start-up costs. Thus the paper concludes that large GDP and high GDP growth rate, business friendly environment and modern communication facilities, such as internet encourage FDI inflow in the developing countries.

Dabla-Norris et al. (2010) documents the relevance of global conditions for FDI to low-income countries and examines the growth implications of FDI inflows in the precrisis period. The paper finds that economic conditions in advanced countries are important factors in explaining cross-country variations in these flows in the recent period. The results indicate that low-income countries are particularly sensitive to changes in the cost of borrowing in advanced countries. This also offers new evidence on the link between FDI inflows and growth in low-income countries. The result shows that growth is increasingly associated with higher FDI inflows and illustrates how the growth dividends of FDI depend crucially on economic fundamentals and macroeconomic stability.

\subsection{Research Methodology}

\subsection{Data Sources}

Data has been taken online mainly from UNCTAD and World Bank website. The period of study is 1990-2009. The continuous data of FDI is available for 53 countries in terms of FDI inflows and inward stock. However, the continuous data on development variables (socio-economic variables) have been available only for 36 countries. Therefore, the study has taken data set of 36 countries which include 20 developed countries and 16 developing countries. The paper has used UNCTAD classification of developed countries and developing countries. Developed countries include Australia, Austria, Belgium- Lumebourg, Canada, Czech Republic, Denmark, France, Germany, Hungary, Ireland, Japan, Netherlands, Norway, Poland, Portugal, Spain, Sweden, Switzerland, United Kingdom and United States. Developing countries include Argentina, Brazil, Chile, China, Egypt, India, Malaysia, Mexico, Morocco, Philippines, South Africa, South Korea, Sri Lanka, Tunisia, Turkey and Venezuela,

\subsection{Principal Component Analysis}

The paper considers developmental variables like population and GDP, in which there which is bound to be a high degree of correlation amongst independent variables. 
There could be three strategies that can be used for dealing with such an econometric problem:

a) Drop all correlated variables, there is a great loss of information.

b) Use Principal Component Analysis (PCA) to determine the "principal variables."

c) Use PCA for formation of a composite index.

The method of PCA has two purposes: data reduction, especially where the variables are interrelated, and compilation of a composite index. For estimating the determinants of international FDI patterns the paper has used a two-step procedure. Firstly, components of FDI patterns are many and are correlated. Variables like GDP, human resources, trade openness, and so on which may be correlated. Under such circumstance it is not possible to use the variables directly in a regression framework on account of multicollinearity. Secondly, when there are a large number of variables then there are needed to collapse them into a single independent variable with the help of PCA. The variable should be such that it captures all the information contained in all the individual variables. In view of these weaknesses of an ordinary regression framework, the paper opts for an alternative method PCA. PCA is based on a linear transformation of the regressors so that they are orthogonal to each other by design. Hence, no information contained in the points in the event space is lost. Second, the normality assumption is not essential in PCA. Third, with such a dispersed set of outcomes, PCA is ideally suited because it maximises the variance rather than minimising the least square distance.

One aim of the empirical work is to evolve a set of composite indices so as to include them as the causal variables consisting of developmental variables such as human resource, infrastructure, labour, market, openness and resources. Hence, there is need to choose the essential variables by a data reduction procedure and arrive at relative weights for the purpose of consolidating these variables into a single index. PCA has been chosen because it has a number of desirable properties. It retains the maximum information, allows the composite of variables to remain uncorrelated amongst each other. The data reduction procedure involves selection of the most relevant variables that capture the maximum information and diverse information. Both the unrotated and rotated solutions explain exactly the same amount of variation in the variables. The choice between them hinges upon the interpretative power of each solution. The component scores (both rotated and unrotated), with respect to the first component are calculated. The most popular orthogonal rotation procedure is Kaiser's Varimax rotation. We therefore retain this procedure.

The following consideration should be kept in mind while applying PCA:

1. For determining the retained component we need a criterion.

2. The PCA methodology tells us the total variance explained by each retained principal component as well as the cumulative percentage of the explained variation. This is a 
measure of the explanatory power of the component for the information content of the procedure.

3. There were various methods of rotation but the most popular method is the Varimax with the Kaiser normalisation. The purpose of the rotation is to make the interpretation of the PCA more meaningful. Method of rotation however retains the same information and explanatory power.

After doing these procedures there was a choice between retained principal components in a regression framework or selecting the principal variables that are associated with each of those components. This involves the Jolliffe procedure. In the first case regression is known as principal component regression and in the second case it is known as principal variable regression. The paper has chosen the latter because it is difficult to interpret the principal component regression. It retains three components which finally land up with three principal variables. The reason is that using the Kaiser criterion of Eigen value less than one leaves only two components while retaining all seven variables leads to multicollinearity.

On the other hand eliminating some variables through PCA does not affect the explanatory power of the equation because the retained variables contain the information of those which are eliminated. The Joliffe's procedure has used for selecting principal variables. It takes up each rotated component and selects the variable that has the highest component score then move to the next component and so on. This way it gets the three principal variables which represent the maximum information and eliminate the variables that are correlated to them and hence create multicollinearity.

Construction of Composite Index: The method for construction of a composite index is given by Jha and Murthy (2006). Once the number of retained principal components is determined and the rotated component scores obtained, then there is the choice of using the principal components as such or selecting certain sub-set of variables from the larger set of variables. Jolliffe proposes selecting one variable to represent each of the retained principal components. The variable that has the highest loading on a component is chosen to represent that component, provided that it has not already been chosen. If it has been chosen, the variable with the next largest loading is selected. The procedure starts with the largest principal component and proceeds to the smallest retained component.

$$
\operatorname{Index}=\sum_{j}^{3} w j x j
$$

where $x j=$ retained variables

$$
\mathrm{wj}=\text { component scores (weights). }
$$

This procedure has been used for creating the following indices:

1. Index of Human Resources

2. Index of Infrastructure 
3. Index of Labour

4. Index of Market

5. Index of Trade Openness

6. Index of Resources

Table 1: Developmental Variable selected through Principal Component Analysis

\begin{tabular}{|l|l|l|l|}
\hline Variable & Variables Included (in PCA) & $\begin{array}{l}\text { Principal Variables } \\
\text { Selected (by PCA) }\end{array}$ & $\begin{array}{l}\text { Composite } \\
\text { Index }\end{array}$ \\
\hline $\begin{array}{l}\text { Human } \\
\text { Resource } \\
\text { (HR) }\end{array}$ & EDUX, EDU_P, POPT & EDUX, EDU_P, POPT & IHR \\
\hline $\begin{array}{l}\text { Infrastructure } \\
\text { (INFRA })\end{array}$ & $\begin{array}{l}\text { ENP, ELP, ATS, ATP, ROAD, } \\
\text { TEL, TEL_P }\end{array}$ & ROAD, TEL, TEL_P & IINFRA \\
\hline $\begin{array}{l}\text { Labour } \\
\text { (LAB) }\end{array}$ & $\begin{array}{l}\text { EMPTEEN, EMP, GDPPC, } \\
\text { LRATE, LFT, POPWA }\end{array}$ & LRATE, LFT, POPWA & ILAB \\
\hline $\begin{array}{l}\text { Market } \\
\text { (MKT) }\end{array}$ & $\begin{array}{l}\text { MKTCAP, COS, POPDEN, } \\
\text { POPL, MFWA, INVA, SVA }\end{array}$ & $\begin{array}{l}\text { MKTCAP, POPDEN, } \\
\text { POPL }\end{array}$ & IMKT \\
\hline $\begin{array}{l}\text { Openness } \\
\text { (OPN) }\end{array}$ & TRES, TOPEN, EXCG & TRES, TOPEN, EXCG & IOPN \\
\hline $\begin{array}{l}\text { Resource } \\
\text { (RES) }\end{array}$ & $\begin{array}{l}\text { GFCF, GDP, GDPPC, GDS, } \\
\text { TNRES }\end{array}$ & $\begin{array}{l}\text { GFCF, GDPPC, } \\
\text { TNRES }\end{array}$ & IRES \\
\hline
\end{tabular}

\subsection{Panel Regression Models}

A common panel data regression model looks like

$\mathrm{y}_{\mathrm{it}}=\mathrm{a}+\mathrm{bx}_{\mathrm{it}}+\epsilon_{\mathrm{it}}$

where $y$ is the dependent variable, $x$ is the independent variable, $a$ and $b$ are coefficients, $i$ and $t$ are indices for individuals and time. The error term $\epsilon_{\mathrm{it}}$ is very important in this analysis. Assumptions about the error term determine whether we speak of fixed effects or random effects. In a fixed effects model, $\epsilon_{\mathrm{it}}$ is assumed to vary non-stochastically over $i$ or $t$ making the fixed effects model analogous to a dummy variable model in one dimension. In a random effects model, $\epsilon_{\mathrm{it}}$ is assumed to vary stochastically over $i$ or $t$ requiring special treatment of the error variance matrix.

The Fixed Effects Model (Least Squares Dummy Variable Model)

The models which capture the individual effects are called fixed effects models. 
Random effects models, on the other hand capture the generalised effects. One kind of the fixed effects panel model would have constant slopes of the independent variables but intercepts would differ according to the cross-sectional (group) unit - in our case, the country. In such cases although there are no significant temporal effects, there are significant differences among countries in this type of model, which is what we would normally expect if we were to analyse FDI flows in general. While the intercept is crosssection (group) specific and in this case differs from country to country, it may or may not differ over time. This is because the main independent variables all refer to the determinants of FDI patterns. The study has interest is in capturing the elasticities of developmental variables in the form of dynamic effects such a model will not suffice. Another type of fixed effects model has differential intercepts and slopes. This kind of model has intercepts and slopes that both vary according to the country grouping. To formulate this model, it would include not only country dummies, but also their interactions with the time-varying covariates. The one big advantage of the fixed effects model is that the error terms may be correlated with the individual effects. Therefore, the individual effects can be captured.

Therefore, the panel model has designed in such a way to capture two effects. The first effect is due to scalar effect. The second effect is due the dynamic changes in the determinants (developmental variables). In the first case the difference dummy with respect to the base country grouping would significant if the initial level of FDI in the developed countries is higher (or lower) than the general trend. In the second case it would show whether the determinants differ between all countries in general and the developed country grouping. Similarly, over a period of time the effect would be captured by the interactive dummy which is a product of the time variable and the country grouping dummy that is in difference form.

\section{FDI Inflows}

The general form of the fixed effects model is:

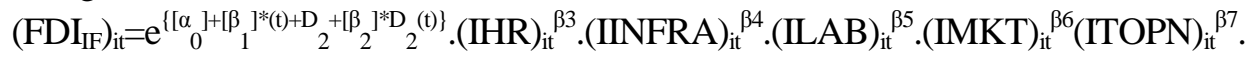
$(\text { IRES) })_{\mathrm{it}}^{\beta 8}$

Taking log on both the side and add error term

$$
\begin{aligned}
& \mathrm{L}\left(\mathrm{FDI}_{\mathrm{IF}}\right)_{\mathrm{it}}=\alpha_{0}+\beta_{1} *(\mathrm{t})+\mathrm{D}_{2}+\left[\beta_{2}\right] * \mathrm{D}_{2}(\mathrm{t})+\beta_{3} \mathrm{~L}(\mathrm{IHR})_{\mathrm{it}}+\beta_{4} \mathrm{~L}(\mathrm{IINFRA})_{\mathrm{it}}+\beta_{5} \mathrm{~L}(\mathrm{ILAB})_{\mathrm{it}}+ \\
& \beta_{6} \mathrm{~L}(\mathrm{IMKT})_{\mathrm{it}}+\beta_{7} \mathrm{~L}(\mathrm{ITOPN})_{\mathrm{it}}+\beta_{8} \mathrm{~L}(\mathrm{IRES})_{\mathrm{it}}+\mathrm{U}_{\mathrm{it}} \\
& \text { where, } \\
& \quad \mathrm{FDI}_{\mathrm{IF}}=\text { Foreign Direct Investment Inflow } \\
& \quad \alpha_{0}=\text { Intercept } \\
& \quad \mathrm{t}=1990,1991 \ldots . . . . . . .(1 \mathrm{a}) \\
& \quad \beta_{1}=\text { Growth rate of world FDI } \\
& \quad \mathrm{D}_{2}=\text { difference dummy for developed countries }
\end{aligned}
$$


$\beta_{2}=$ Difference in growth rate of developed countries' FDI

$\beta_{3}, \beta_{4}, \beta_{5}, \beta_{6}, \beta_{7}$, and $\beta_{8}=$ Elasticities of developmental variables

IHR = Composite Index of Human Resource

IINFRA = Composite Index of Infrastructure

ILAB = Composite Index of Labour

IMKT $=$ Composite Index of Market

ITOPN $=$ Composite Index of Trade Openness

IRES $=$ Composite Index of Resources

FDI Inward Stock

The general form of the fixed effects model is:

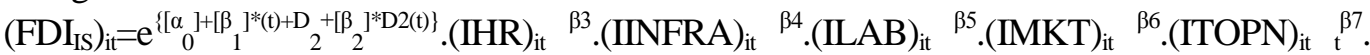
$(\text { IRES })_{\text {it }}{ }^{\beta 8}$

Taking $\log$ on both the side and add error term

$\mathrm{L}\left(\mathrm{FDI}_{\mathrm{IS}}\right)_{\mathrm{it}}=\alpha_{0}+\beta_{1} *(\mathrm{t})+\mathrm{D}_{2}+\left[\beta_{2}\right] * \mathrm{D}_{2}(\mathrm{t})+\beta_{3} \mathrm{~L}(\mathrm{IHR})_{\mathrm{it}}+\beta_{4} \mathrm{~L}(\mathrm{IINFRA})_{\mathrm{it}}+\beta_{5} \mathrm{~L}(\mathrm{ILAB})_{\mathrm{it}}+$ $\beta_{6} \mathrm{~L}(\mathrm{IMKT})_{\mathrm{it}}+\beta_{7} \mathrm{~L}(\mathrm{ITOPN})_{\mathrm{it}}+\beta_{8} \mathrm{~L}(\mathrm{IRES})_{\mathrm{it}}+\mathrm{U}_{\mathrm{it}}$

where, $\mathrm{FDI}_{\mathrm{IS}}=$ Foreign direct investment inward stock

$\alpha_{0}=$ Intercept

$\mathrm{t}=1990,1991, \ldots . .2009$

$\beta_{1}=$ Growth rate of world FDI

$\mathrm{D}_{2}=$ Difference dummy for developed countries

$\beta_{2}=$ Difference in growth rate of developed countries' FDI

$\beta_{3}, \beta_{4}, \beta_{5}, \beta_{6}, \beta_{7}$, and $\beta_{8}=$ Elasticities of developmental variables

IHR = Composite Index of Human Resource

IINFRA = Composite Index of Infrastructure

ILAB = Composite Index of Labour

IMKT $=$ Composite Index of Market

IOPN $=$ Composite Index of Trade Openness

IRES $=$ Composite Index of Resources

\subsection{Empirical Results and Analysis}

\subsection{Principal Component Analysis of World Developmental Variables}

\section{Human Resource}

Human resource represents skilled manpower, which would have an impact on the FDI patterns. For measuring the variable PCA have identified variables- Expenditure on Education (EDUX), Primary Education, Pupils (EDU_P) and Total Population (POPT) and it has been explained about how this could be developing a composite index, that 
summaries the information contained in all these variables. It involves three steps: The first step involves the Kaiser-Meyer-Olkin (KMO) test which tells us about the adequacy of sample and appropriateness of PCA as a methodology. In general, value of KMO test should be on higher side. In case of human resource, the value is 0.45 , which is just reasonable. Bartlett test measures sphericity which states about suitability of using of PCA. If it is statistically significant then it represents suitability of using principal component analysis. In case of human resource, Bartlett test is statistically significant (Table 2a). The next step is to find out the number of principal components which are being retained. In this case, there are three variables and all three variables have been selected because we imposed a condition to select minimum three variables. Therefore total variance explained by these three variables is 100 percent (Table 2b). In the next step, we used Varimax rotation method, to arrive at rotated component score (Table $2 \mathrm{c}$ ). This would enable to have a better interpretation of components. Moreover it helps in generating the value weights obtained from the factor loading for constructing the composite index.

Table 2: Results of Principal Component Analysis of Human Resource

(a) KMO and Bartlett's Test

\begin{tabular}{|l|l|c|}
\hline \multicolumn{2}{|l|}{ Kaiser-Meyer-Olkin Measure of Sampling Adequacy } & .452 \\
\hline \multirow{3}{*}{ Bartlett's Test of Sphericity } & Approx. Chi-Square & 2732.534 \\
\cline { 2 - 3 } & Df & 3 \\
\cline { 2 - 3 } & Sig. & .000 \\
\hline
\end{tabular}

(b) Total Variance Explained

\begin{tabular}{|c|c|c|c|c|c|c|}
\hline \multirow{2}{*}{ Component } & \multicolumn{3}{|c|}{ Initial Eigenvalues } & \multicolumn{3}{c|}{ Extraction Sums of Squared Loadings } \\
\cline { 2 - 7 } & Total & $\begin{array}{c}\text { \% of } \\
\text { Variance }\end{array}$ & $\begin{array}{c}\text { Cumulative } \\
\text { \% }\end{array}$ & Total & $\begin{array}{c}\text { \% of } \\
\text { Variance }\end{array}$ & $\begin{array}{c}\text { Cumulative } \\
\text { \% }\end{array}$ \\
\hline 1 & 2.013 & 67.094 & 67.094 & 2.013 & 67.094 & 67.094 \\
\hline 2 & .976 & 32.531 & 99.624 & .976 & 32.531 & 99.624 \\
\hline 3 & .011 & .376 & 100.000 & .011 & .376 & 100.000 \\
\hline
\end{tabular}

(c) Rotated Component Matrix

\begin{tabular}{|c|c|c|c|}
\hline \multirow{2}{*}{ Variable } & \multicolumn{3}{|c|}{ Component } \\
\cline { 2 - 4 } & $\mathbf{1}$ & $\mathbf{2}$ & $\mathbf{3}$ \\
\hline EDU_P & $\mathbf{9 9 7}$ & .030 & -.074 \\
\hline POPT & .993 & .085 & $\mathbf{. 0 7 6}$ \\
\hline EDUX & .057 & $\mathbf{. 9 9 8}$ & .002 \\
\hline
\end{tabular}

Source: Authors estimation 
The rotated component scores of EDU_P, EDUX and POPT are 0.997, 0.998 and 0.076 respectively (Table 2c). These scores are used for construction of composite index of human resource.

Composite Index of Human Resources

$$
\mathrm{I}_{\mathrm{HR}}=0.997 \mathrm{EDU} \_\mathrm{P}+0.998 \mathrm{EDUX}+0.076 \mathrm{POPT}
$$

\section{Infrastructure}

Infrastructure refers to the facilities through which others resources can be efficiently and optimally used. For measuring this variable, the following variables has been used Energy Production (ENP), Electricity Production (ELP), Air Transport (ATS), Air Transport-Passengers (ATP), Road Sector Energy Consumption (ROAD), Telephone Lines (TEL) and Telephone Lines (per 100 People) (TEL_P). It shall be used to develop composite index that summaries the information contained in all these variables. The value of KMO test is 0.815 , which is high and supports sample adequacy for PCA. Bartlett test suggests infrastructure variable is statistically significant (Table 3a). In the next step, the retained variables selected are ROAD, TEL, and TEL_P. Total variance explained by these retained components is 96.56 percent (Table $3 \mathrm{~b}$ ). Rotated component scores of ROAD, TEL and TEL_P are 0.896, 0.910 and 0.987 respectively (Table 3c).

Table 3: Results of Principal Component Analysis of Infrastructure

(a) KMO and Bartlett's Test

\begin{tabular}{|l|l|c|}
\hline Kaiser-Meyer-Olkin Measure of Sampling Adequacy & .815 \\
\hline \multirow{3}{*}{ Bartlett's Test of Sphericity } & Approx. Chi-Square & 9192.486 \\
\cline { 2 - 3 } & Df & 21 \\
\cline { 2 - 3 } & Sig. & .000 \\
\hline
\end{tabular}

\section{(b) Total Variance Explained}

\begin{tabular}{|c|c|c|c|c|c|c|}
\hline \multirow{2}{*}{ Component } & \multicolumn{4}{|c|}{ Initial Eigenvalues } & \multicolumn{3}{c|}{ Extraction Sums of Squared Loadings } \\
\cline { 2 - 7 } & Total & $\begin{array}{c}\text { \% of } \\
\text { Variance }\end{array}$ & $\begin{array}{c}\text { Cumulative } \\
\text { \% }\end{array}$ & Total & $\begin{array}{c}\text { \% of } \\
\text { Variance }\end{array}$ & $\begin{array}{c}\text { Cumulative } \\
\text { \% }\end{array}$ \\
\hline 1 & 5.290 & 75.572 & 75.572 & 5.290 & 75.572 & 75.572 \\
\hline 2 & .993 & 14.187 & 89.759 & .993 & 14.187 & 89.759 \\
\hline 3 & .479 & 6.840 & 96.599 & .479 & 6.840 & 96.599 \\
\hline 4 & .151 & 2.164 & 98.763 & & & \\
\hline 5 & .065 & .929 & 99.691 & & & \\
\hline 6 & .014 & .199 & 99.891 & & & \\
\hline 7 & .008 & .109 & 100.000 & & & \\
\hline
\end{tabular}


(c) Rotated Component Matrix

\begin{tabular}{|c|c|c|c|}
\hline \multirow{2}{*}{ Variable } & \multicolumn{3}{|c|}{ Component } \\
\cline { 2 - 4 } & $\mathbf{1}$ & $\mathbf{2}$ & $\mathbf{3}$ \\
\hline ROAD & $\mathbf{. 8 9 6}$ & .407 & .096 \\
\hline ATP & .885 & .428 & .133 \\
\hline ATS & .869 & .348 & .216 \\
\hline ELP & .716 & .683 & .094 \\
\hline TEL & .350 & $\mathbf{. 9 1 0}$ & .090 \\
\hline ENP & .532 & .805 & -.030 \\
\hline TEL_P & .148 & .039 &. $\mathbf{9 8 7}$ \\
\hline
\end{tabular}

Source: Authors estimation

Using rotated component scores mentioned above, the Composite Index of Infrastructure is given as:

$$
\mathrm{I}_{\text {INFRA }}=0.896 \mathrm{ROAD}+0.910 \mathrm{TEL}+0.987 \mathrm{TEL} \_\mathrm{P}
$$

\section{Labour}

Labour represents raw human work force, representing the cost side. For measuring this variable, the following variables have been identified- Employment, 15-24 age (EMPTEEN), Employment (EMP), GDP Per Person (GDPPC), Labour Participation Rate (LRATE), Labour Force, Total (LFT) and Population Working Ages (POPWA). It shall be used to develop composite index that provides the information contained in all these variables. The value of KMO test is 0.666 , supporting sample adequacy. Bartlett test suggests labour variable is statistically significant (Table 4a). In this case, we have six variables and the retained variables are LRATE, LFT and POPWA. Total variance explained by these three variables is 89.01 percent (Table $4 \mathrm{~b}$ ). The rotated component scores of LRATE, LFT and POPWA are 0.932, 0.860 and 0.969 respectively. Using these scores, the Composite Index of Labour is developed as follows:

$$
\mathrm{I}_{\mathrm{LAB}}=0.932 \mathrm{LRATE}+0.860 \mathrm{LFT}+0.969 \mathrm{POPWA}
$$

Table 4: Results of Principal Component Analysis of Labour

(a) KMO and Bartlett's Test

\begin{tabular}{|l|l|c|}
\hline \multicolumn{2}{|l|}{ Kaiser-Meyer-Olkin Measure of Sampling Adequacy } & .666 \\
\hline \multirow{3}{*}{ Bartlett's Test of Sphericity } & Approx. Chi-Square & 2909.533 \\
\cline { 2 - 3 } & Df & 15 \\
\cline { 2 - 3 } & Sig. & .000 \\
\hline
\end{tabular}


(b) Total Variance Explained

\begin{tabular}{|c|c|c|c|c|c|c|}
\hline \multirow{2}{*}{ Component } & \multicolumn{3}{|c|}{ Initial Eigenvalues } & \multicolumn{3}{c|}{ Extraction Sums of Squared Loadings } \\
\cline { 2 - 7 } & Total & $\begin{array}{c}\text { \% of } \\
\text { Variance }\end{array}$ & $\begin{array}{c}\text { Cumulative } \\
\text { \% }\end{array}$ & Total & $\begin{array}{c}\text { \% of } \\
\text { Variance }\end{array}$ & $\begin{array}{c}\text { Cumulative } \\
\text { \% }\end{array}$ \\
\hline 1 & 2.983 & 49.715 & 49.715 & 2.983 & 49.715 & 49.715 \\
\hline 2 & 1.566 & 26.093 & 75.808 & 1.566 & 26.093 & 75.808 \\
\hline 3 & .793 & 13.211 & 89.018 & .793 & 13.211 & 89.018 \\
\hline 4 & .363 & 6.051 & 95.069 & & & \\
\hline 5 & .243 & 4.054 & 99.123 & & & \\
\hline 6 & .053 & .877 & 100.000 & & & \\
\hline
\end{tabular}

(c) Rotated Component Matrix

\begin{tabular}{|c|c|c|c|}
\hline \multirow{2}{*}{ Variable } & \multicolumn{3}{|c|}{ Component } \\
\cline { 2 - 4 } & $\mathbf{1}$ & $\mathbf{2}$ & $\mathbf{3}$ \\
\hline LRATE & $\mathbf{. 9 3 2}$ & .183 & .102 \\
\hline EMP & .929 & .243 & .104 \\
\hline EMPTEEN & .908 & -.113 & .097 \\
\hline LFT & .345 & $\mathbf{. 8 6 0}$ & .080 \\
\hline GDPPC & .268 & -.673 & .562 \\
\hline POPWA & .076 & .002 & $\mathbf{. 9 6 9}$ \\
\hline
\end{tabular}

Source: Authors estimation

\section{Market}

Market is a place where production is used for consumption. For measuring this variable, the following variables have identified- Market Capitalization of Listed Companies (MKTCAP), Listed Domestic Companies (COS), Population Density (POPDEN), Population in Largest City (POPL), Manufacturing-Value Added (MFWA), IndustryValue Added (INVA) and Services-Value Added (SVA). The value of KMO test is 0.824, and the Bartlett test suggests market variable is highly statistically significant (Table 5a). In this case, seven variables have taken and as before, we impose the condition that three variables have to be selected. The retained variables are MKTCAP, POPL and POPDEN. Total variance explained by these variables is 91.37 percent (Table 5b). Using Varimax rotation, the rotated component scores of MKTCAP, POPL and POPDEN are 0.962, 0.929 and 0.993 respectively. These scores are used for construction of composite index of Market (Table 5c).

Composite Index of Market

$$
\mathrm{I}_{\mathrm{MKT}}=0.962 \mathrm{MKTCAP}+0.929 \mathrm{POPL}+0.993 \mathrm{POPDEN}
$$


Table 5: Results of Principal Component Analysis of Market

(a) KMO and Bartlett's Test

\begin{tabular}{|l|l|c|}
\hline \multicolumn{2}{|l|}{ Kaiser-Meyer-Olkin Measure of Sampling Adequacy } & .824 \\
\hline \multirow{3}{*}{ Bartlett's Test of Sphericity } & Approx. Chi-Square & 7823.383 \\
\cline { 2 - 3 } & Df & 21 \\
\cline { 2 - 3 } & Sig. & .000 \\
\hline
\end{tabular}

(b) Total Variance Explained

\begin{tabular}{|c|c|c|c|c|c|c|}
\hline \multirow{2}{*}{ Component } & \multicolumn{3}{|c|}{ Initial Eigenvalues } & \multicolumn{3}{c|}{ Extraction Sums of Squared Loadings } \\
\cline { 2 - 7 } & Total & $\begin{array}{c}\text { \% of } \\
\text { Variance }\end{array}$ & $\begin{array}{c}\text { Cumulative } \\
\%\end{array}$ & Total & $\begin{array}{c}\text { \% of } \\
\text { Variance }\end{array}$ & $\begin{array}{c}\text { Cumulative } \\
\%\end{array}$ \\
\hline 1 & 4.734 & 67.628 & 67.628 & 4.734 & 67.628 & 67.628 \\
\hline 2 & 1.072 & 15.318 & 82.947 & 1.072 & 15.318 & 82.947 \\
\hline 3 & .590 & 8.424 & 91.371 & .590 & 8.424 & 91.371 \\
\hline 4 & .432 & 6.171 & 97.542 & & & \\
\hline 5 & .135 & 1.928 & 99.470 & & & \\
\hline 6 & .034 & .487 & 99.957 & & & \\
\hline 7 & .003 & .043 & 100.000 & & & \\
\hline
\end{tabular}

(c) Rotated Component Matrix

\begin{tabular}{|c|c|c|c|}
\hline \multirow{2}{*}{ Variable } & \multicolumn{3}{|c|}{ Component } \\
\cline { 2 - 4 } & $\mathbf{1}$ & $\mathbf{2}$ & $\mathbf{3}$ \\
\hline MKTCAP & $\mathbf{. 9 6 2}$ & .093 & -.043 \\
\hline SVA & .961 & .200 & -.012 \\
\hline INVA & .907 & .354 & .052 \\
\hline MFVA & .897 & .355 & .067 \\
\hline COS & .695 & .363 & .141 \\
\hline POPL & .328 & $\mathbf{. 9 2 9}$ & .106 \\
\hline POPDEN & .023 & .092 & $\mathbf{. 9 9 3}$ \\
\hline
\end{tabular}

Source: Authors estimation

\section{Trade Openness}

Trade openness refers to openness of domestic country for international trade activities. It facilitates free movement of goods and services amongst countries. For measuring the variable we have identified the following three variables- Total reserves (TRES), Trade Openness (TOPEN) and Official exchange rate (EXCG). The value of $\mathrm{KMO}$ test is 0.485 , which is reasonable. Bartlett test suggests trade openness variable is 
significant at 10 percent level of significance (Table 6a). As we have imposed a condition of three variables to be retained, hence all three have been retained and therefore total variance explained by these three variables is 100 percent (Table 6b). The rotated component scores of EXCG, TRES and TRADE are 1.00, 0.999 and 0.999 respectively (Table 6c). These scores are used for construction of composite index of trade openness. Composite Index of Trade Openness

$$
\mathrm{I}_{\mathrm{TOPN}}=1.00 \mathrm{EXCG}+0.999 \mathrm{TRES}+0.999 \mathrm{TOPEN}
$$

\section{Table 6: Results of Principal Component Analysis of Trade Openness}

(a) KMO and Bartlett's Test

\begin{tabular}{|l|l|c|}
\hline \multicolumn{2}{|l|}{ Kaiser-Meyer-Olkin Measure of Sampling Adequacy } & .485 \\
\hline \multirow{3}{*}{ Bartlett's Test of Sphericity } & Approx. Chi-Square & 6.958 \\
\cline { 2 - 3 } & Df & 3 \\
\cline { 2 - 3 } & Sig. & .073 \\
\hline
\end{tabular}

(b) Total Variance Explained

\begin{tabular}{|c|c|c|c|c|c|c|}
\hline \multirow{2}{*}{ Component } & \multicolumn{3}{|c|}{ Initial Eigenvalues } & \multicolumn{3}{c|}{ Extraction Sums of Squared Loadings } \\
\cline { 2 - 7 } & Total & $\begin{array}{c}\text { \% of } \\
\text { Variance }\end{array}$ & $\begin{array}{c}\text { Cumulative } \\
\mathbf{\%}\end{array}$ & Total & $\begin{array}{c}\text { \% of } \\
\text { Variance }\end{array}$ & $\begin{array}{c}\text { Cumulative } \\
\text { \% }\end{array}$ \\
\hline 1 & 1.086 & 36.191 & 36.191 & 1.086 & 36.191 & 36.191 \\
\hline 2 & 1.020 & 34.002 & 70.193 & 1.020 & 34.002 & 70.193 \\
\hline 3 & .894 & 29.807 & 100.000 & .894 & 29.807 & 100.000 \\
\hline
\end{tabular}

(c) Rotated Component Matrix

\begin{tabular}{|c|c|c|c|}
\hline \multirow{2}{*}{ Variable } & \multicolumn{3}{|c|}{ Component } \\
\cline { 2 - 4 } & $\mathbf{1}$ & $\mathbf{2}$ & $\mathbf{3}$ \\
\hline EXCG & $\mathbf{1 . 0 0 0}$ & -.014 & -.020 \\
\hline TRES & -.014 & $\mathbf{. 9 9}$ & -.042 \\
\hline TOPEN & -.020 & -.043 & $\mathbf{. 9 9 9}$ \\
\hline
\end{tabular}

Source: Authors estimation

\section{Resource}

Resource includes Gross Fixed Capital Formation (GFCF), Gross Domestic Products (GDP), GDP Per Capita (GDPPC), Gross Domestic Savings (GDS) and Total Natural Resources (TNRES). These resources are used to developed composite index, which gives information contained in these variables. The value of KMO test is 0.560 , which represents sample adequacy for PCA. Bartlett test suggests resource variable is significant (Table 7a). 
In this case, five variables have taken and the retained variables are GFCF, GDPPC and TNRES. Total variance explained by these variables is 98.02 percent (Table 7b). The rotated component scores of GFCF, GDPPC and TNRES are 0.989, 0.982 and 0.994 respectively (Table $7 \mathrm{c}$ ). These scores loading are used for construction of composite index of resource as follows:

$$
\mathrm{I}_{\mathrm{RES}}=0.989 \mathrm{GFCF}+0.982 \mathrm{GDPPC}+0.994 \mathrm{TNRES}
$$

Table 7: Results of Principal Component Analysis of Resource

(a) KMO and Bartlett's Test

\begin{tabular}{|l|l|c|}
\hline Kaiser-Meyer-Olkin Measure of Sampling Adequacy & .560 \\
\hline \multirow{3}{*}{ Bartlett's Test of Sphericity } & Approx. Chi-Square & 4820.623 \\
\cline { 2 - 3 } & Df & 10 \\
\cline { 2 - 3 } & Sig. & .000 \\
\hline
\end{tabular}

(b) Total Variance Explained

\begin{tabular}{|c|c|c|c|c|c|c|}
\hline \multirow{2}{*}{ Component } & \multicolumn{3}{|c|}{ Initial Eigenvalues } & \multicolumn{3}{c|}{ Extraction Sums of Squared Loadings } \\
\cline { 2 - 7 } & Total & $\begin{array}{c}\text { \% of } \\
\text { Variance }\end{array}$ & $\begin{array}{c}\text { Cumulative } \\
\text { \% }\end{array}$ & Total & $\begin{array}{c}\text { \% of } \\
\text { Variance }\end{array}$ & $\begin{array}{c}\text { Cumulative } \\
\text { \% }\end{array}$ \\
\hline 1 & 3.078 & 61.552 & 61.552 & 3.078 & 61.552 & 61.552 \\
\hline 2 & 1.016 & 20.328 & 81.879 & 1.016 & 20.328 & 81.879 \\
\hline 3 & .807 & 16.143 & 98.022 & .807 & 16.143 & 98.022 \\
\hline 4 & .094 & 1.877 & 99.899 & & & \\
\hline 5 & .005 & .101 & 100.000 & & & \\
\hline
\end{tabular}

(c) Rotated Component Matrix

\begin{tabular}{|c|c|c|c|}
\hline \multirow{2}{*}{ Variable } & \multicolumn{3}{|c|}{ Component } \\
\cline { 2 - 4 } & $\mathbf{1}$ & $\mathbf{2}$ & $\mathbf{3}$ \\
\hline GFCF & $\mathbf{. 9 8 9}$ & .118 & -.068 \\
\hline GDS & .968 & .125 & -.066 \\
\hline GDP & .960 & .152 & -.062 \\
\hline GDPPC & .172 & $\mathbf{. 9 8 2}$ & -.079 \\
\hline TNRES & -.080 & -.076 & $\mathbf{. 9 9 4}$ \\
\hline
\end{tabular}

\subsection{World Inward FDI and Economic Development (Panel Regression Method)}

FDI Inflows: The minimum level of international FDI inflow is significant. The annual compound growth rate was 6.1 percent and for the period of twenty years. However the growth rate of developed countries as a group was 2.5 percent higher although it does 
not represent statistically significant difference because $p$-value is 0.116 . Therefore this is weak trend although it can be deemed to be significant at 15 percent level of significance (Table 8). Essentially FDI inflows in developing countries have been growing at a faster rate. In terms of determinants of the six developmental variables, four determinants are found to be significant.

Table 8: Regression Statistics of World FDI Inflows and Developmental Variables

\begin{tabular}{|l|c|c|c|c|}
\hline & Coefficients & Standard Error & t Stat & P-value \\
\hline Intercept & -110.750 & 24.144 & -4.587 & $0.000^{*}$ \\
\hline DUMMY (D) & -49.077 & 31.696 & -1.548 & 0.122 \\
\hline TIME & 0.061 & 0.012 & 5.022 & $0.000^{*}$ \\
\hline TIME*D & 0.025 & 0.016 & 1.574 & $\mathbf{0 . 1 1 6}$ \\
\hline IHR & -0.344 & 0.065 & -5.286 & $0.000^{*}$ \\
\hline IINFRA & 0.581 & 0.103 & 5.638 & $0.000^{*}$ \\
\hline ILAB & -0.090 & 0.070 & -1.287 & $\mathbf{0 . 1 9 9}$ \\
\hline IMKT & 0.238 & 0.043 & 5.492 & $0.000^{*}$ \\
\hline ITOPN & -0.050 & 0.064 & -0.785 & $\mathbf{0 . 4 3 3}$ \\
\hline IRES & 0.260 & 0.117 & 2.233 & $0.026^{* *}$ \\
\hline R Square & 0.62 & \multicolumn{2}{|c|}{ Adjusted R Square } & 0.61 \\
\hline
\end{tabular}

Source: Authors estimation

$* 1 \%$ level of significance and ** 5\% level of significance.

ANOVA

\begin{tabular}{|l|c|c|c|c|c|}
\hline & Df & SS & MS & F & Significance F \\
\hline Regression & 9 & 1290.03 & 143.34 & 127.08 & 0.00 \\
\hline Residual & 710 & 800.80 & 1.13 & & \\
\hline Total & 719 & 2090.83 & & & \\
\hline
\end{tabular}

Labour is found to be significant only at 20 percent level whereas openness is not significant. Human resource which represents skilled manpower bears a negative sign and has elasticity equal to -0.34 ; thus it is relatively inelastic. The negative sign can be explained in the following way. Firstly, developed countries are essentially responsible for FDI outflows and are the ones that have higher proportion of skilled manpower. Therefore it is more likely that they have a positive elasticity in case of FDI outflows. Secondly, a 
similar result obtained with the labour variable, although it is significant at 20 percent level. This shows that international FDI inflows are not influenced by availability of raw labour. This could be attributed to the growth of knowledge economy. One of the main driving forces of FDI is management skills and technology. Therefore, it is unlikely that FDI go into traditional labour-intensive industry. This explains the negative sign. Although the high p-value can be attributed to variations particularly in the case of FDI inflow which is more dominated by developing countries. One of the important determinants is infrastructure and in this case the elasticity is less than one but magnitude is quite high that is 0.58 ; also it is significant. Therefore, it clearly indicates gains from infrastructure development play a major role in FDI inflows. A one percent increase in infrastructure development would lead to almost a 0.6 percent increase in FDI inflows. This is by far largest magnitude. Another important determinant is resource whose elasticity is 0.26 and the coefficient is statistically significant. Market is also found to be important and significant and its elasticity is 0.24 (Table 8). The results show that first and foremost international FDI inflows are efficiency-seeking because infrastructure results in external economies of scale. Secondly they are resource-seeking and thirdly market-seeking.

FDI Inward Stock: Inward stock represents accumulated investment. Therefore, it represents stable patterns. Hence, standard errors of all variable are much lower than that of inflow. This results in the general affirmation that the above results hold good in the long-run. It represents the long term trend which is not affected by year to year changes.

The minimum level of international FDI inward stock is highly significant. The annual compound growth rate was 5.8 percent for the period of 20 years. However, the growth rate of developed countries as a group was 4.3 percent higher and it is statistically significant. Essentially, FDI inward stock in developed countries is growing at a faster rate. In terms of socio-economic determinants, all developmental variables are found significant. Human resource and openness are found to be significant at 10 percent level of significance. Other four determinants are highly significant at one percent. Openness bears a negative sign and has elasticity equal to -0.080 ; thus it is relatively inelastic. Human resource which represents skilled manpower has elasticity equal to -0.082 , and hence it is inelastic. The negative sign can be explained in the following way. Developed countries are essentially responsible for FDI outflows and are the ones that have higher proportion of skilled manpower. Therefore, they are more likely to have a positive elasticity in case of FDI outflows. A similar result is obtained with the labour variable and it is significant at one percent level. This shows that international FDI are not influenced by availability of raw labour. This could be attributed to the growth of knowledge economy. One of the main driving forces of FDI is management skills and technology. Therefore, it is unlikely that 
FDI go into traditional labour-intensive industry. This explains the negative sign. The low p-value can be attributed to stable pattern of FDI inward stock in the long-run. This shows a stable and significant trend (Table 9).

Table 9: Regression Statistics of World FDI Inward Stock and Developmental Variables

\begin{tabular}{|l|c|c|c|c|}
\hline & Coefficients & Standard Error & t Stat & P-value \\
\hline Intercept & -102.536 & 16.084 & -6.375 & $0.000^{*}$ \\
\hline DUMMY (D) & -85.946 & 21.114 & -4.070 & $0.000^{*}$ \\
\hline TIME & 0.058 & 0.008 & 7.138 & $0.000^{*}$ \\
\hline TIME*D & 0.043 & 0.011 & 4.082 & $0.000^{*}$ \\
\hline IHR & -0.082 & 0.043 & -1.890 & $0.059^{* *}$ \\
\hline IINFRA & 0.392 & 0.069 & 5.705 & $0.000^{*}$ \\
\hline ILAB & -0.330 & 0.046 & -7.105 & $0.000^{*}$ \\
\hline IMKT & 0.283 & 0.029 & 9.825 & $0.000^{*}$ \\
\hline ITOPN & -0.080 & 0.043 & -1.868 & $0.062^{* *}$ \\
\hline IRES & 0.312 & 0.078 & 4.020 & $0.000^{*}$ \\
\hline R Square & 0.79 & Adjusted R Square & & 0.79 \\
\hline
\end{tabular}

Source: Authors estimation

$* 1 \%$ level of significance and $* * 5 \%$ level of significance.

ANOVA

\begin{tabular}{|l|c|c|c|c|c|}
\hline & Df & SS & MS & F & Significance F \\
\hline Regression & 9 & 1337.89 & 148.65 & 297.01 & 0.00 \\
\hline Residual & 710 & 355.36 & 0.50 & & \\
\hline Total & 719 & 1693.25 & & & \\
\hline
\end{tabular}

One of the most important determinants is infrastructure and in this case the elasticity is less than one but magnitude is quite high at 0.39 ; also it is significant. Therefore it clearly indicates the role of infrastructure and gains from infrastructure development. A one percent increase in infrastructure development would lead to almost a 0.4 percent increase in FDI stock. This is by far the largest magnitude. The next variable in importance is resource whose elasticity is 0.31 and which is statistically significant. Market whose elasticity is 0.28 and is significant turns out to be the next important variable. It shows that first and foremost international FDI inward stocks are efficiency-seeking because infrastructure results in external economies of scale. Secondly they are resourceseeking and thirdly market-seeking (Table 9). 
On a comparative basis, it can be seen that the magnitude of infrastructure elasticity is greater in case of inflow because this indicates annual changes and represents marginal change whereas the coefficient for stock is lower in magnitude but its standard error is also much lower. This represents the consistent long-term trends. In a particular year it may be possible to have higher inflows due to growth of infrastructure but stable pattern results in a 20 percent lower rate of growth in international FDI inflows (Table 8 and Table 9).

\subsection{Conclusion}

We find that for FDI inflows, the annual growth rate is 6.2 percent. Infrastructure, market and resource are found to be significant determinants of FDI with a positive impact. Labour and trade openness are not significant. Human resource coefficient is negative and significant. It indicates efficiency, market and resource-seeking FDI. With respect to FDI inward stock, the annual growth rate is 5.8 percent. However, growth rate of developed countries as a group is 4.3 percent higher. All developmental variables are found to be significant. On a comparative basis, it can be seen that the magnitude of infrastructure elasticity is greater in case of inflow because this indicates annual changes and represents margin change whereas the coefficient for stock is lower in magnitude but its standard error is also much lower. This represents the consistent long-term trends. In short, the results establish certain basic principles of FDI theory in terms of efficiency-seeking FDI, resource-seeking FDI and market-seeking FDI.

\section{References}

Banga, R. (2003). The Export Diversifying Impact of Japanese and U.S. Foreign Direct Investments in Indian Manufacturing Sector. Indian Council for Research on International Economic Relations (ICRIER) Working Paper 110, September.

Banga, R. (2003). Impact of Government Policies and Investment Agreements on FDI Inflows. Indian Council for Research on International Economic Relations (ICRIER), Working Paper 116, November.

Bhanu Murthy, K.V. (2011). State of Environment in South Asia. In R. Jha (Ed.), Handbook of South Asian Economics (pp.289-308), Routledge, London. 
Dunning, John H. (1977). Trade, Location of Economic Activity, and the Multinational Enterprise: A search for an Eclectic Approach. In The International Allocation of Economic Activity. B. Ohlin, P. O. Hesselborn, P. M. Wijkman (Ed.), New York: Holmes and Meier.

Dunning, John H. (1998). Location and the Multinational Enterprise: A Neglected Factor? Journal of International Business Studies, 29(1): 45-66.

Jha, R. \& Bhanu Murthy, K.V. (2006). Environmental Degradation Index. A Survey of Composite Indices Measuring Country Performance, A UNDP/ODS Working Paper, By Romina.

Mottaleb, Khondoker Abdul (2007). Determinants of Foreign Direct Investment and Its Impact on Economic Growth in Developing Countries. MPRA Paper No. 9457.

Norris, E., Honda, J., Lahreche, A. \& Verdier, G. (2010). FDI Flow to Low income Country: Global Drivers and Growth Implications. IMF Working Paper $W P / 10 / 132$.

Palit, A. \& Nawani, S. (2007). Technological Capability as a Determinant of FDI Inflows: Evidence from Developing Asia \& India. ICRIER Working Paper No. 193.

\section{Websites}

www.unctad.org

www.worldbank.org

www.ssrn.com 
74 | FOCUS: Journal of International Business, Vol. 2, Issue 1

\section{$\underline{\text { Appendix }}$}

DEVELOPMENTAL VARIABLES

\section{Human Resources}

EDUX

EDU_P

POPT

\section{Infrastructure}

ENP

ELP

ATS

ATP

ROAD

TEL

TEL_P

\section{Labour}

EMPTEEN

EMP

GDPPC

LRATE

LFT

POPWA

\section{Market}

MKTCAP

COS

POPDEN

POPL

MFWA

INVA

SVA

\section{Openness}

TRES
Adjusted savings: education expenditure (current US\$)

Primary education, pupils

Population, total

Energy production (kt of oil equivalent)

Electricity production $(\mathrm{kWh})$

Air transport, freight (million ton-km)

Air transport, passengers carried

Road sector energy consumption (kt of oil equivalent)

Telephone lines

Telephone lines (per 100 people)

Employment to population ratio, ages 15-24, total (\%)

Employment to population ratio, 15+, total (\%)

GDP per person employed (constant 1990 PPP \$)

Labour participation rate, total (\% of total population ages $15+$ )

Labour force, total

Population in age 15-64 (\% of total)

Market capitalization of listed companies (current US\$)

Listed domestic companies, total

Population density (people per sq. km of land area)

Population in largest city

Manufacturing, value added (current US\$)

Industry, value added (current US\$)

: $\quad$ Services, etc., value added (current US\$) 
Inward Foreign Direct Investment and Economic Development $\mid 75$

TOPEN : Trade Openness

EXCG : Official exchange rate (US\$ per LCU, period average)

\section{Resources}

GFCF : Gross fixed capital formation (current US\$)

GDP : Gross Domestic Products (current US\$)

GDPPC : $\quad$ GDP per capita (current US\$)

GDS : Gross domestic savings (current US\$)

TNRES: $\quad$ Total natural resources rents (\% of GDP). 